\title{
ПРОПОВЕДЬ НА ПРАЗДНИК АКАФИСТА БОГОРОДИЦЕ В РУКОПИСИ XVII В.: ИСТОРИКО-ЛИТЕРАТУРНЫЙ КОНТЕКСТ И АРХИТЕКТОНИКА ${ }^{1}$
}

\author{
A Sermon on the Feast of the Akathist to the Mother of God \\ in a 17th-century Manuscript: \\ Historical and Literary Context and Architectonics
}

\author{
Larisa Soboleva
}

DOI: 10.17846/CL.2021.14.2.84-97

\begin{abstract}
SOBOLEVA Larisa. A Sermon on the Feast of the Akathist to the Mother of God in a 17th century Manuscript: Historical and Literary Context and Architectonics. The article examines the manuscript collection of sermons of the 17th century "Statir“ (Moscow, Russian State Library, Collection of Rumyantsev 411). The book was compiled by a priest from the Church of the Praise of the Mother of God in Orel-gorodok on the River Kama, the estate of the Stroganovs. The manuscript contains 156 homilies for various feasts, from which the text written for the service in honor of the feast of the Mother of God is selected. The historical context of the choice of the sermon's name is explained and the poetics of the sermon is examined. The main originality of the text is seen in the author's vivid presence, the idea of overcoming sinfulness is given a personal evaluation by the preacher. The author seeks to create the effect of people's unity in communion with the perfect image of the Mother of God. The Precept creates a synthesis of epic eschatological expectation and lyrical treatment of the soul. The sermon reveals individual feelings in line with the biography and personal qualities of the author, foreshadowing the future development of Russian philosophical lyricism.
\end{abstract}

Keywords: lyrical empathy, Akathist to the Mother of God, the name of the church, homily, sermon, spiritual literature of 17 th century

\section{Введение}

Христианское богослужение обладало особым типом креативности, основанном на сложном единении в пространстве храма визуального, музыкального и словесного искусств. Синтез позволял создавать особую атмосферу возвышенной эмотивности. В службе радостные похвалы сакральным силам и умилительное восхищение праведностью святых соединялись с драматическими переживаниями греховности земного существования человека и убежденности в возможности ее преодоления. Храмовое пространство и богослужение выполняли исторически обусловленные многообразные

Исследование выполнено при финансовой поддержке гранта Российского научного фонда (проект № 19-18-00186 “"Культура Духа” vs “Культура Разума”: Интеллектуалы и Власть в Британии и России в эпоху Перемен (XVII-XVIII вв.)»). 
Проповедь на праздник Акафиста Богородице в рукописи XVII в.: историко-литературный контекст и архитектоника

функции, структурируя и придавая жизненному процессу необходимое целеполагание. Восприятие молитвословия подразумевало активное пробуждение творческой энергии человека, направленной к спасению, а следовательно, актуализировался лирический элемент, связанный с личностным отношением к сакральному миру. Это лежало в основе поэтической симфонии человека и Бога - идеи, продолженной темой божественного вдохновения в поэзии Нового времени.

Церковная служба имела, помимо прославляющей, дидактическую функцию, формируя у верующих идеал чувства-переживания и следующей из этого модель поведения. В драматургии богослужения сочетаются разнообразные по характеру и генезису виды литературы, представленные молитвословиями, цитатами и притчами из Святого писания, обращениями к пастве священнослужителя, вербальным и невербальным общением клира и паствы. Назидание-поучение присутствовало в разной степени во всех частях службы, наиболее зримо учительное начало демонстрировалось в проповедях, читавшихся священником на праздники подвижного и неподвижного сакрального календаря. ${ }^{2}$ В текстах сочетаются похвалы празднику с обличениями греховности и призывами к выбору пути спасения.

\section{Проповедь в «переходное время» XVII века}

Проповеднические тексты многофункциональны, они вбирают в себя, помимо задач прославления праздника, тему обличения греховности земной жизни, и, являя собой поддержку словом человеку в преодолении его слабостей, должны способствовать борьбе с телесными и душевными искушениями. Проповеди привлекались из специальных богослужебных «учительных» книг или авторских сборников, а также могли составляться храмовым священником определенного статуса самостоятельно. ${ }^{3}$ В текстах различных проповедников варьировались соотнесенные $\mathrm{c}$ церковными праздниками темы и приводилась аргументация, вызванная жизненными условиями и запросами паствы.

Развитие проповеди, связующей профанный и сакральный миры, будучи неравномерным в разные периоды русской религиозной культуры, обретает особый вес в «переходный» XVII век (Yeremin 1948, 363). Оживление жанра авторской проповеди во второй половине века свидетельствует о новом представлении деятельного участия человека в формировании социальной жизни. Церковная проповедь, отзываясь на противоречивость мира, воспроизводила, отрицая или утверждая, новые черты в поведении человека, показывала столкновение разных оценок явлений и людей. Феномен «оцерковления» человека в предпетровский период отражает ситуацию как кризиса, так и утопических надежд удержать прежними формами духовного творчества ситуацию под контролем (Panchenko 1984, 104-112). Человек этого времени, по характеристике М. Плюхановой, «Являлся неоднозначным, не равным самому себе, выявляя в себе сакральную ипостась... Еще погруженный в старые представления, но уже лишенный стабилизирующих основ древнерусской жизни, десоциализированный, смятенный человек мог понять себя лишь как величину сакральную и, чтобы обрести равновесие, перемещал себя из обыденной жизни в сакральный мир» (Pliuhanova 1982,

2 Учительное слово по Уставу могло быть произнесено на вечерне, на утрени и на Литургии. Наиболее оправданным считается произнесение поучений и житий на вечерних богослужениях.

3 Церковь в своих канонах усваивает право литургийной проповеди только лицам, имеющим благодать священства, и притом только епископам и пресвитерам (58-е Правило апостолов; Правило 64-е IV Вселенского собора). 
184). Объяснимым оказывается внимание к бытованию проповеди как факту устной речевой традиции, по крайней мере, ожидание ее распространения в таком варианте. В этом сказывалась надежда церковных интеллектуалов, владеющих искусством слова, на эффект обновления системной картины мира и углубления христианской аксиологии. Культура устного храмового слова не стала обязательным навыком для каждого священника, и вряд ли в условиях будущего сверхнормативного государственного устройства имела перспективы развития в направлении индивидуализации проповеди, но последней трети XVII - начале XVIII века, потенциальные возможности жанра были реализованы в появлении сборников авторских проповедей. Русская православная традиция столкнулась с вызовами, пришедшими с проповедниками из западных присоединенных земель, где умение выстраивать поучение соединялось с искусством похвалы земной власти, что на первых порах вызывало энтузиазм и поддержку при дворе царя и российской элиты. Пафос поучения и глорификация в авторитетных произведениях Кирилла Транквиллиона, Иоанникия Галятовского, Лазаря Барановича творчески претворяется затем в сочинениях Симеона Полоцкого (как в богослужебных - «Обед душевный», «Вечеря душевная», так и в текстах придворной культуры - «Рифмологион»). Продолжением этого творческого направления станут сочинения Димитрия Ростовского, Стефана Яворского, Феофана Прокоповича и др. (Yeremin 1948). Успешная карьера Симеона Полоцкого, предопределенная талантом писателя, убеждение окружающих в результативности (политической и культурной) влияния произнесенного и написанного слова, обнародованного и преподнесенного государю в нужный момент, формировали уверенность в возможности участия творческой индивидуальности в обрисовке аксиологических постулатов на основе христианской аргументации. Достоинство жанра для литературы состояло в возможности включать в текст описание личных переживаний священника. Их удельный вес, глубина субъективности и разнообразие зависели от смелости и готовности проповедника открыть себя пастве, чему способствовали жанровые каноны. Вектор лирического высказывания был намечен именно в этом типе литературы, аккумулирующей образное воплощение эмотивности из разных источников и жанров (притчи, пророчества, толкования, песнопения и т. п.). Искусство синтеза зависело от таланта, но очевидно, что в логике литературного процесса это был путь к отделению в словесности нового времени индивидуального «я» от субстанциальной целостности нации «ее состояний, образа мыслей, действий и судеб» (Hegel 1958, 232). Личностная рефлексия и осознание доминанты изображения собственного переживания в проповеди антиномично соединяется с дидактикой поучения, обрисовывая динамику становления нового качества писательского и читательского горизонта.

Талант проповедника оказался востребованным не только в столичном - контексте (феномен Симеона Полоцкого, Дмитрия Ростовского и др.), но и в далеком географически, но не по самоощущению роли в социуме, Орле-городке на Каме - центре владений уральских землевладельцев - «именитых людей» Строгановых. Именно здесь анонимным протопопом из церкви во имя Похвалы Богородицы был создан эквивалент учительным сочинениям Симеона Полоцкого - рукописный сборник, в составе которого 156 авторских проповедей на праздники Триодного круга, Минейные, а также «на случай». ${ }^{4}$ Автор назвал

4 Москва, РГБ. Собр. Румянцева № 411. Сборник слов и поучений «Статир». XVII в. (третья четверть). 815 лл. размер: 30,7 на 19,8, п/у одного почерка, авторский счет листов трижды начинается с первого. Записи на форзацных листах, где могла быть информация об авторстве, утрачены, переплетные листы второй половины XVIII в. Переплет поновлен, XIX в., на обороте верхней крышки экслибрис Румянцева. (Vostokov 1842, 629-633. № 411). О месте написания 
Проповедь на праздник Акафиста Богородице в рукописи XVII в.: историко-литературный контекст и архитектоника

его «Статир», используя сопоставление своего труда с ловлей рыбы апостолом Петром и платой золотой монетой, по слову Христа, «за Мя за ся» (Soboleva 2020, 343).

Рукопись включает в себя проповеди различного характера, соответствующие ритуальному времени и отвечающие потребностям паствы. Характер проповедей, их тональность и цель произнесения также не единообразны: от Слов похвальных, соответствующих типу праздника, разъясняющих смысл основных догматов христианского вероучения, до проповедей с обличительной доминантой и задачей формирования морального постулата и житейского поведения. ${ }^{5}$ В исследованиях об истории церкви XVII в. упоминания о сборнике неоднократно включаются, но преимущественно как свидетельство развития культуры письменности Прикамья, ${ }^{6}$ конкретные тексты сборника до настоящего времени мало опубликованы и недостаточно изучены. ${ }^{7}$

\section{Церковь «Похвалы Богородице»: исторический контекст именования}

В разнообразии именований христианской церкви можно обнаружить определенную связь с пониманием заказчиками и строителями духа времени и особенностями пространства, где возводился храм. Особое почитание Богородицы было присуще русской религиозности, начиная с момента крещения, исторические формы воплощения богородичного культа в искусстве - многогранная тема, имеющая солидную библиографию. Книжники XVII в. находились в уверенности об особой приверженности христианству славянских народов, и о покровительстве Богородицы Руси, что находило отражение в многочисленных чудотворных иконах и праздниках, связанных с мариелогией (Bogdanov 2011, 432). Религиозная семантика богородичных праздников дополнялась их историко-патриотическим и социо-культурным звучанием. ${ }^{8}$ Выбор имени «похвальской»

рукописи свидетельствует полустертая запись: «Начася льта 7191 [1683] го(да) м(е)с(я)ца апріллія в 8 д(е)нь написася же 192 [684] го(да) августа в 20(е)нь при державъ б(о)гоизбранных ц(а)рей и правовърных г(о)с(у)д(а)рей двою братови Іоаннь Аксіевичъ и Петрб Аксіевичь в вотчинь имянитого ч(е)л(ове)ка Григорія Димитріевича Строганова на Орль-городкъ, на ус(тье) Яйвырьки» (л. 9 об., І сч.). Здесь и далее при передаче текста рукописи сохраняем грабему п, юс мальй передается через я, омега через о, і сохраняем в отдельных значимых случаях, титлы раскрываем и вводим сокращенные графемы, Знаки препинания расставляем при смысловой необходимости.

Общую характеристику содержания «Статира» см.: [Soboleva 2012]

6 Приведем наиболее значимые имена исследователей XIX - XX вв., привлекавших рукопись «Статира»: И. К. Яхонтов, М. А. Паторжанский, А. И. Клибанов, А. В. Карташов, И. П. Еремин, А. С. Елеонская, П. Т. Алексеев, А. А. Введенский, Д. М. Буланин, Л. С. Соболева и др.

7 Обращение к рукописи до последнего времени осуществлялось через издание сокращенных текстов в переводе на русский язык XIX в. богословом И. К. Яхонтовым для ознакомления приходского духовенства с историей проповеди (журнал «Духовная беседа», 1858 г.) [Yakhontov 1858]. Отрывки из этого издания были воспроизведены в учебных курсах М. А. Паторжинского [Patorzhinsky 1879, 289-303] и П. В. Знаменского [Znamensky 1896, 304-305].

8 Зримым примеров служит праздник Покрова Пресвятой Богородицы, в котором, начиная с момента возникновения, включалось особое представление о Церкви как покрове, ограде и защите (Pliuhanova 1995, 52-63). В XVI - XVII вв. в. это становится востребованным, о чем свидетельствует строительство Иваном Грозным храма Покрова на Красной площади (более известного как «Храм Василия Блаженного»), Храма в Медведково (1653), построенного Дмитрием Пожарским, Покровского монастыря, выстроенного государем Михаилом Романовым (1635). Икона Казанской божьей матери со второй половины XVII в. считалась покровительницей дома Романовых, и праздники во имя иконы из местночтимых - московских и казанских - стали общероссийскими. 
церкви мог быть предопределен несколькими факторами. Предприниматели из рода Строгановых, происходившего из Русского Севера, в 1558 г. «бьют челом» государю Ивану IV о пожаловании им прикамских земель. Просьба сопровождается образным описанием «пустых» мест и обещанием успешной колонизации во имя интересов государства, главным аргументом было то, что в царскую казну «с того места пошлина никакая не бывала» (Andreev 2000, 225-226). Инициатива возымела действие: Строгановы получили наделы и освобождение от налогов на 20 лет. Основное условие состояло в обязательном строительстве землевладельцами укрепленных городков для защиты жителей «для береженья от ногайских людей и от иных орд» (Ibid.) Эти задачи были более чем насущными, в 1572 г. под Орлом-городком при нападении местных племен на новопоселенцев было убито 78 человек. Настаивая на суровом наказании нападавших, государь пишет в грамоте о бережном отношении к тем, кто готов подчиниться Москве, и союзе с теми, кто выступает против «изменщиков» (Ibid., 236-237). Празднование победы над язычеством и уверенность в опеке Богородицы, магия ее присутствия при упоминании имени вызвали к жизни именование храма в честь богослужебного текста / иконы / праздника Акафиста Богородицы. ${ }^{9}$

Возник этот тип изображения в поздневизантийское время, дополнив собой предшествующие иконные образы. Богородица появлялась на иконе в «венке» из пророков, их лица выражали величайшую любовь и поклонение. История появления Акафиста подробно рисуется в «Повести о Неседальном», размещаемой в конце Постной Триоди. Установление изначально местночтимого праздника во Влахерне (пригороде Константинополя) было связано с идеей избавления христианской столицы от угрозы нападения и завоевания персами / аварами (по разной датировке от VII до IX в.). Появление иконы в честь праздника оказывается существенно для истории Константинополя и оптимистичного ожидания спасения от Защитницы мира. Календарное положение праздника (суббота 5 недели Великого поста) - в предвестии Пасхальных торжеств должно было приободрить верующих в ожидании завершения скорбных дней. Акафист особое песнопение, прославляющее Богородицу и состоящее из двенадцати икосов и кондаков, ${ }^{10}$ получил широкое распространение в восточном христианстве (Psarev 1909). Тогда же «в русле стремления проиллюстрировать отдельные части литургического действа, прокомментировать в образах наиболее известные поэтические тексты» (Gromova $2005,10)$ была создана икона «Похвала Богоматери» в иконографии «Одигитрия» (сейчас находится в Дионисиатском монастыре на Афоне).

На Руси тема была актуализирована в XII в. по традиционной версии усилиями князя Андрея Боголюбского. Праздники в честь охранительно-защитной функции Богородицы (Покрова, Акафиста, Ризы Богородицы) были выделены в системе богослужения

9 Иконы, посвященные раскрытию смысла эпитета или метафорической символики при воспевании Богородицы в Акафисте и иных церковных песнопениях, именуют «Акафистный образ». Иконографические схемы строятся по принципу иллюстрирования того или иного эпитета, которым Богоматерь величается в Акафисте. Акафистная иконография становится универсальным воплощением как всех предыдущих Богородичных иконографических типов, так и визуальной кульминацией мариологического христианства, «отразив в иконографических образах все возможные символические смыслы и значения, относящиеся к Богородице» (Yazykova 1994, 92).

10 История и художественные особенности Великого Акафиста неоднократно становились предметом исследований. Обзор см.: (Turilov; Kazachkova; Nikiforova 2000). 
Проповедь на праздник Акафиста Богородице в рукописи XVII в.: историко-литературный контекст и архитектоника

православной церковью. ${ }^{11}$ В концепте богородичных праздников присутствовала социальная составляющая - «общественное звучание» - благотворного покровительства Богородицы (Pliuhanova 1995, 52-63). Это было осознано летописцем при передаче сведений о встрече отца Андрея Боголюбского, суздальского князя Юрия Долгорукова (правнука византийского императора Константина Мономаха) с князем Святославом Ольговичем (Новгород-Северским) 4 апреля 1147 г., который, получив приглашение, «приди ко мнъ брате въ Московъ», посетил брата «и тако любезно цъловастас въ д(е) нь Плтокъ на Похвалоу с(вя)тьи Б(огороди)ци и тако быша весели. на оутрии же д(е)нь повель Гюрги оустроити шбъдъ силенъ и створи ч(е)сть великоу имъ» (Polnoe sobranie 1908, Stlb. 339). Упоминание автором летописи праздника Похвалы, имеющего семантику многократного спасения Царьграда от врагов, не только историческая деталь, а указание на сакральный смысл покровительства Богородицей союза князей, об обязательствах и целях их сотрудничества, об ответственности перед Богом. Княжеский «обед силен» в праздник Акафиста должен был ритуально удостоверить взаимные обещания. Существенным является закрепление этим праздником за Москвой аллюзии на столицу православного мира - Константинополь. Год встречи князей в праздник «Похвалы» становится для истории годом основания Москвы под покровительством Богородицы. Перипетии военных набегов и противостояние с Ордой соотносятся с идеей защиты Богородицей Царьграда. К зримой демонстрации преемственности столиц примыкает основание митрополитом Ионой в 1459 г. в Успенском соборе придела в честь праздника Похвалы Богородицы. Именно в нем происходило избрание и нарекание митрополитов русской церкви, которых на следующий день поставляли в чин. В росписи стен собора присутствуют мотивы из Жития Богородицы и образы Акафиста, выполненные в XVII в. (Gromova 2005). Из функционального аспекта, наиболее свойственного иконографии данного периода, выделяется ракурс «духовное материнство по отношению к верующим», где на иконах представлена Богоматерь в роли «мать всего земного на земле», в иерархическом аспекте ракурс «предводитель небесного воинства» - Богоматерь представлена защитницей Московского царства (Ibid.). В дальнейшем бытовании в православной традиции празднично-богородичные иконы соотносятся либо с событиями государственной и религиозно-национальной защиты, либо со сбережением витальной силы человека и избавления его от болезней. ${ }^{12} \mathrm{~B}$ описаниях русских путешественников XII - XV веков часто упоминаются посещения Влахернского храма, где хранились риза и пояс Богородицы, происходили чудеса спасительного свойства (Maleto 2003). Чудеса, связанные с иконами Владимирской, Казанской, Смоленской Божьей Матери и др., в русской истории вплетены в событийную канву противостояния междоусобицам и вражеским нападениям.

K XVI в. сложился извод иконописного изображения Акафиста, где Богородица, изображена сидящей на престоле, над ней фигура благословляющего Христа. Вокруг, спускаясь к основанию иконы, фигуры пророков, каждый из которых протягивает Богородице рукописание с текстами их сочинений и символы Богородицы, упомянутые в Акафисте. ${ }^{13}$ Богородичные иконы широко представлены в художественном наследии Строгановых. Близко к этому времени данный сюжет был задействован для росписи

11 В данной статье не актуальна дискуссионная литература о времени и месте происхождения праздника. См.: (Slovo na Pokrov 1987).

12 Несколько иную, благодарственную, но более частную семантику имел храм Похвалы Богородицы, возведенный в Кремле в 1652 г. боярином Ильей Милославским, ставшим царским тестем (1648 г.).

13 Символы Богородицы: Аввакум с горой, Иезекииль с вратами, Иеремия с каменной Скрижалью 
сольвычегодского храма Благовещенья Пресвятой Богородицы (освященный в 1563 г.), воздвигнутом по инициативе Строгановых. Иконописный ансамбль, в котором развивается тема Боговоплощения, заступничества за род человеческий и искупления Спасителем греховной природы человека, по типу изображения был близок к комплексу икон Благовещенского собора Московского Кремля, что было своего рода «самоутверждением, декларацией особого положения представителей рода Строгановых в обществе, если не равного, то, во всяком случае, близкого царскому» (Pivovarova 2017, 141).

Стремлением утвердить идею покровительства Богородицей при освоении новых территорий становится строительство в Орле-городке на берегу Камы (центре владений Строгановых с конца XVI - до начала XVIII в.) церкви во имя Похвалы Богородицы. ${ }^{14}$ Событийная канва «Повести о Неседальном», заключенная в охране православных людей Богородицей, в конце XVI в. была актуальна на окраине государства.

Указать точный год закладки и освящения церкви не позволяют сохранившиеся документы. Разрешение на создание пограничного городка было получено Григорием Аникиевичем Строгановым от Ивана Грозного в 1564 г. О том, что церковный проект был изначально включен в строительство Орла-городка, свидетельствует «Житие» святого Трифона Вятского (1546 - 1612), известного исторического и религиозного деятеля конца XVI - XVII в., основателя Успенского монастыря в Хлынове (Вятке). Житие повествует о подвижнике, как тот «прииде в Пермь великую, въ Строгановыхъ городокъ, рекомый Орловъ. И ту живяше блаженный, странствуя нищетою годищное время, пребывая у церкви Божией», где обитал до 1565 г. (Zhitie 1868, 18). Храм Похвалы Пречистый Богородицы, еще деревянный, «о пяти верхах, кресты и главы обиты железом белым» впервые был описан Кайсаровым в Писцовой книге Великопермских вотчин Строгановых 1623 - 24 года (Dmitriev 1892, 163-176). Богатое состояние храма может свидетельствовать о нескольких поколениях вкладчиков и его основании в конце XVI в. (Kazarinova, Sysoeva, 2017). Иконы в честь праздника Похвалы Богородице присутствовали не только в этом храме, но и в других церквях вотчины.

Род Строгановых был причастен к историческим событиям российского масштаба (Mezenina, Mosin, Mudrova, Nekliudov 2007). Будучи в XVI в. на восточном рубеже российского государства, они взяли на себя ответственность за охрану границ и продвижение на восток. Овладение новыми территориями не проходило мирно, опасность набегов заставляя действовать решительно, надеяться приходилось на себя, укрепляя дух верой в помощь высших сил. Выбор церковного праздника, в именовании которого Прикамье символически соединялось не только с Москвой, но и Царьградом, могло быть обусловлено политическими амбициями Строгановых. Впечатляющий материал о культуре строгановского региона, собранный исследователями к сегодняшнему дню, дает основание согласиться с характеристикой искусствоведа А. Преображенского, что Строгановы «отличались особой чуткостью к судьбам мира и склонностью

Завета, Иаков с лествицей, Аарон с цветущим жезлом, Гедеон с руном, Моисей с горящей купиной, Даниил с горой, Давид с ковчегом, Исаия с клещами. Внизу - Валаам со звездой.

14 Количество церквей, названных в честь Акафиста в истории русской церкви невелико, что объясняется с уникальностью именования праздника, художественный канон иконы Акафиста пронизан идеей письменной похвалы (в руках пророков воспроизводятся манускрипты с формулами глорификации Богоматери). Это своего рода элитарное посвящение в церковном именословии, праздник не обладал потенциальной возможностью конкурировать спосвящениями двунадесятым праздникам или святым. В реестре российских православных храмов среди 23361 именований церквей только 43 - в честь Похвалы Богородицы, из них 6 возникли до 18 в. См.: (Statistika po naimenovaniyam). 
Проповедь на праздник Акафиста Богородице в рукописи XVII в.: историко-литературный контекст и архитектоника

к размышлениям о пути человека к спасению души, а православия - к финалу своей исторической миссии» (Preobrazhenskiy 2017, 228).

С образом Богородицы в составе сборника «Статир» соотносятся десять проповедей. ${ }^{15}$ Помимо традиционных праздников (Рождество, Сретение, Введение во Храм, Успение), автор подробно описывает присутствие Богородицы и ее плача при погребении Сына Божия, а в Слове на пятницу пасхальной недели восхваляется чудо явления Божьей Матери.

Одной из самых эмоционально насыщенных проповедей в сборнике является уникальный текст, написанный в честь престольного праздника «Поучение въ субботу пятую святаго поста» (лл. 129-136 об., III сч.). Проповедь расположена среди праздников, прикрепленным к дням года (памяти святым) и «на случай». ${ }^{16}$

Престольные праздники были широко распространены на всей территории России, и Прикамье не было исключением. Будучи вызваны религиозным обиходом, они встраивались в народную культуру, становились знаками семейно-родовой общности и территориального единения. В Прикамье среди престольных праздников было немало, посвященных иконам Божией матери (Владимирской, Грузинской, Донской, Казанской, Тихвинской, Неопалимой купины и др.). ${ }^{17}$ (Chernyh 2014, 52). Обычно собиралась многочисленная публика, приезжали знакомые и родственники из соседних поселков и деревень. Во время праздника, кроме службы, могли быть крестные ходы к почитаемым водным источникам, а также обходы домов прихожан. Традиция «гостевания» увеличивала число прихожан на службе, ее посещение было обязательным для всех гостей (Tultceva 2001, 127-130, 148-149). Престольный праздник становился фактором, объединяющим людей не только территориально, но патриархальной родовой близостью. Его атмосфере было присуще настроение веселья, и торжествовала традиция широкого гулянья, выражавшая идею витальности родового единства. У проповедника были основания для произнесения Поучения и напоминания христианского смысла праздника.

\section{Оригинальность Поучения из «Статира»}

Внимание к теме Похвалы Богородицы в русском православии было поддержано обращением к западно-украинским церковным авторам. Поучения на этот праздник не представлены в традиционном Учительном Евангелии, в Евангелии учительном Кирилла Транквиллиона-Ставровецкого (Рахманов, 1619), книгах проповедей Симеона Полоцкого, но «Слово на суботу 5 с (едмицы)...» обнаруживается в сборнике «Мечь духовный» (Киев, 1666) Лазаря Барановича (Lazar’ Baranovich 1666, 412 об.-421 об.). Ее основное содержание составляют просьбы к Богородице об «освобождении» от напастей в пустыне, в граде, на реке и на море в сочетании с похвалой. Тексту предшествует заставка, где дан вариант иконы Акафиста с изображением пророков. Выделяет особо этот праздник его последователь

15 Слова 3, 6, 111 из первой части; 3, 6, 10, 20, 21, 26 - из второй.

16 Проповедь помещена автором во второй части сборника (л. 129-137, III сч.) между Словом 25 «Поучение в день принесения Нерукотворнаго образа, и от яковых нас злых Христос избави, и о еже не бояти, аще и укосним, но прибегнем к Владыце и на безумную седину» (9 августа) и Словом 27 «Поучение на Рождество Иоанна Предтечи, и о чюдном житии его и похвала о добродетелех» (24 июня).

17 Наличие в календаре Русской церкви порядка 260 чудотворных и литургически празднуемых икон в иконографии Богоматери свидетельствует о востребованности образа в национальной религиозной культуре (Uspenskiy 2001, 6). 
польско-украинский проповедник Антоний Радивиловский. В сборнике своих гомилий под названием «Огородок Марии Богородицы...» (Киев, 1676) он со свойственной ему велеречивостью и энциклопедичностью публикует 6 слов, посвященных празднику (Antoniy Radivilovskiy 1676, 920-969, нумерация постраничная). В качестве заставки проповедник также использует гравюру с близким изображением иконы Акафиста. Автор обращается не только к библейскому мифу, но и пересказывает исторические события, приведшие к появлению праздника.

Произведение из сборника «Статир» не повторяет украинских проповедников, отличается ярким лирическим пафосом и стройной организацией. Сложная архитектоника текста возникает как следствие нескольких задач, успешно претворяемых автором в художественную структуру. Доминантной является раскрытие сути праздника и системы символико-метафорических уподоблений Богородицы в соответствие с иконописным сюжетом. С этой задачей сопряжена дидактическая цель, достигаемая в процессе коммуникации. Успешность воздействия на ума и сердца слушателей видится автором в соединении высокого накала богословской образности и веры в телеологию спасения с личными переживаниями проповедника, горестно сомневающегося в благочестии паствы и сокрушающегося о своих грехах. В этой проповеди, как и в других поучениях сборника, внимание слушателя обостряется вследствие прихотливого сочетания ритмических частей, объединенных еще и рифмой (чаще всего глагольной) и прозаических высказываний. Ритмические фрагменты придают законченную форму эмоциональным воззваниям. Прозаические настраивают слушателя на глубину библейской истории, выявляя соотношение небесного и земного в осмыслении образа Пречистой Богородицы.

Автор сам определяет специфику проповеди, предлагая «бесъду пресладкую и веселую, слушателемъ на утьшение, а Тебъ, о, Б(о)гоизбранная Д(е)в(и)це, на похваление» (л. 129). ${ }^{18}$

Наполняя храмовое пространство «беседой», автор все пророчества вводит через глаголы устной речи, кроме традиционного «рече» и «глаголя», автор дает ряд синонимических конструкций: сказа, увъряя, гласъ мой возвышаю, яснъйши сказуетъ, согласуется, воспъваетъ, сотвори ми пресладкий гласъ твои, похвалимъ единодушно и т. п. В Поучении используется прием многоголосия. Автор изначально опирается на выделение своего голоса, описывая чувства и эмоции, перебивая прославление собственными репликами: «Н(ы)нъ д(у)ша моя радости наполнися и с(е)рдце мое веселиемъ играетъ», прописывая и проговаривая текст от первого лица: «гласъ мой возвышаю», но затем, призывая к празднованию «православный народе» начинает величать Богородицу от лица всех, употребляя местоимение мы: «мы днесь ублажимъ...».

Включает, цитируя Евангелие, автор глас Богородицы, в котором слышится весть, принесенная архангелом Гавриилом и слова Елизаветы, уверившие Марию в чудесном зачатии. Следуя за Акафистом и расширяя словесно иконописный сюжет, автор не только перечисляет всех 12 ветхозаветных пророков, предрекших рождение Сына Божия и давших символические толкования, раскрывающие суть Пречистой Девы как связующего звена вечного и преходящего, как возможности земному существу достичь небесного совершенства, но, цитируя отрывки из пророчеств, создает своеобразный прославляющий хор, сменяющий похвалу автора. Традиционный набор пророчеств иконного ряда автор дополняет, обращаясь к книге «Песнь песней», что вносит в пророчески-афористические высказывания лирическую ноту. Переживания «премудрого песнопевца» поддерживают

18 Здесь и далее при цитировании указываем листы рукописи в авторской нумерации по третьему счету. 
Проповедь на праздник Акафиста Богородице в рукописи XVII в.: историко-литературный контекст и архитектоника

эмоциональное выражение личных чувств автора и становятся своего рода крещендо в симфонии голосов. От возглашаемых пророками смыслов предметы перестают быть равными себе, наполняясь новым одухотворенным содержанием, что должно было задеть разум слушателя и приподнять его над обыденностью. Автор далее вновь включает похвалу от паствы, основанную на желании понять сложную сущность происходящего.

Из всех особенностей, свойственных индивидуальному стилю автора, надо выделить приверженность к антиномичности, пронизывающей разные элементы художественной организации текста. Принцип антиномичности был заложен в христианской философии изначально, став залогом развития, сохраняя в себе идею непостижимости и познаваемости мира одновременно. Идея Богочеловеческой природы Христа, непорочного зачатия, смерти, ставшей Воскресением - эти принципы антиномичности претворяются автором в Поучении, развивая тему совершенства Божией матери в несовершенном мире, который живет, преодолевая искушение и в ожидании спасения. Церковь, утверждая «кровную связь Богоматери с падшим человечеством, несущим последствия первородного греха» видит, что «из всего рода человеческого Она первая достигла той цели, которая поставлена перед всеми людьми - полного преображения всего человеческого естества» (Uspenskiy 2001, 28).

От разъяснения смысла явления Богородицы через семантику символов автор переходит к призыву: «Вы же, о, возлюбленная ми братия и о(т)цы, приложите д(у)ши и сердца к моимъ словесемъ» похвалить Богородицу и дает чередование хайретизмов, основанное на Акафисте. Среди хайретизмов встречается парафраз из Учительного Евангелия Кирилла Транквиллиона (Слово на Сретение). Завершая хайретизмы, автор вновь обращается к общему хору: «Сего ради, о, любезнбйшии мои, послушати возопиемъ свътлымъ гласомъ веселымъ с(е)рдцемъ и возрадованными д(у)шами принесем пъсни похвалныя» (л. 134 об.), привлекая к высказыванию благодарности и похвалы всю паству. И обращаясь к Песни Песней (гл. 2, 2), вводит в общую похвалу нотки сердечного восхищения: «Пребл(а)гословеннъйшая Д(е)во во дщерахъ Сионских, яко Кринъ бл(а) говонный посредъ терния, и яко С(о)лнце, посредъ звъздъ сияющи зарею свъта б(о)ж(е)ственнаго. Радуйся, Сокровище чистоты и с(вя)тости...» (л. 134 об.)

Завершением поучения становится прямое обращение-пожелание к социуму «купно всякого возраста и сана», выделенного автором в зависимости от достатка («богатымъ и нищимъ»), возраста («старцем и юношамъ»), статуса («с(вя)щеннымъ и мирским»), пола («женам и д(е)вамъ»), власти («гордящиеся» и «рабы»), священникам («премудрии словосказатели»). И от каждого автор требует: «принесите достойная Достойнбй», устанавливая своеобразное равновесие: дара Богородицы - Сына Божия - и даров людских: от богатых - милостыня, от судий - справедливость, от гордящихся «д(у)хъ сокрушенъ», от рабов - послушание и т. п. Завершая и обращаясь ко всем присутствующим, автор проговаривает постулат о значении священства: «...исторгните изъ с(е)рд(е)цъ вашихъ всякий злый плодъ, и всякая скверная и гнилая дъяния, и помещите предъ ногами о(т)ецъ вашихъ д(у)х(о)вных...» (л. 135). Таким образом, достигается важная цель проповеди возможность каждому ощутить себя в одном пространстве с Богородицей, приобщиться к совершенству мира через ее образ.

Проповедник ввергает паству в пространство своих переживаний от несовершенства мира и людей и со свойственной ему страстью оратора восклицает: «Горе ми, окаянному... Кая бо ми полза от лучь с(о)лн(е)чных, егда печаль васъ ради многою помрачаетъ очи тмою», раскрывая свое состояние как результат увиденных прегрешений и далее разворачивает описание через цитату-сравнение из Псалтири (Пс 37, 11) «Поистиннъ не лжу, егда увижу неправы обычаи ваши, тогда, аки мертвъ, являюся, яко раслабленъ, 
яко иступленъ умомъ и по прор(о)ческому слову, о, яко свътъ очию моею, и той нъсть со мною!» (л. 136 об.). Автор готов к любым упрекам («хухнанию») и обидам не только для будущего спасения паствы, но и для мирного жительства «здъ». Наказание же их попрекам автор предвидит от Бога, проявляя при этом свойственное эпохе сочетание уничижения и амбиций: «Мы же вси братия, единъ же нашъ наставник есть Хр(ис)тосъ, есть же и в братии - единому повельвати, а инымъ послушати. Есть же в васъ мнози порицают мя разглаголником и ласкателемъ, и о семъ н(ы)нъ ни единаго слова имамъ имъ изрещи, каковаго мя помышляют, таковую и мзду от Бога восприимутъ» (л. 136 об.). Порицая и обличая грешников, проповедник оборачивает острие высказываний против себя, утверждая, что ему надо учиться у паствы, и ее благополучие составляет его счастье: «Молю вы и колънъ касаюся, исполните радость мою, сие токмо надежду имъю, сие ми постъ, сие ми м(о)л(и)тва, да желаю преспъяния вашего во благое... яко все мое веселие вы есте...» (л. 136).

Антиномичность отражается в композиции, где сочетаются в одном пространстве текста сугубо личные переживания автора и отношение всего христианского мира, в едином хоре сливаются слова пророков и архангела с прославлением от имени грешников, сознающих свое ничтожество. Образ Богородицы показывается в его антиномической сущности, которая постоянно подчеркивается автором: Госпожа и раба, отроковица и Матерь безмужная, Лъствице одушевленная, земли Ширшая, небеси Пространнъйшая, Вмъстилище Невмъстимаго, Престолъ Вышняго, всъх Царя Съдалище, Ковчеже одушевленный, Пристанище небурное, Прибъжище теплое, Забрало твердое, Стъна непреоборимая и т. п. Все эти определения воплощают творчески переосмысленную автором христианскую антиномичность, соединившую библейский символический параллелизм и античную риторику.

В Предисловии к проповедям автор подчеркивает недостаток своего богословского образования. Возможно, это соответствует действительности, и автор преимущественно занимается самообразованием в библиотеке Пыскорского монастыря. Таким образом, талант автора и его уверенность в нужности проповедей, поддержанное положением патрона Г. Д. Строганова, приводят к уникальному результату - созданию оригинальных текстов, не ограниченных жестко правилами риторических норм, более воплощающих авторское вдохновение, проповедническое негодование, личное ощущение трагического падения нравов. Приведенная проповедь - светлый лирический гимн Богородице, в поэтике которого присутствует барочная напряженность. Поэтике барокко присущи, по замечанию Виппера. «обостренный интерес к динамическим аспектам действительности, к преисполненному драматизма движению характеров, событий и обстоятельств, к осмыслению и воспроизведению противоречий, служащих источником этого неумолимо устремляющегося вперед жизненного потока...» (Vipper 1969, 24). Анонимный автор оказывается в самом эпицентре этого движения, парадоксальным образом воспроизводя эти интенции времени в классическом церковнослужебном жанре. 
Проповедь на праздник Акафиста Богородице в рукописи XVII в.: историко-литературный контекст и архитектоника

\section{REFERENCES}

\section{Archive source}

Statir. Москва, Российская государственная библиотека. Собрание Румянцева № 411. Сборник слов и поучений «Статир». XVII век (80-90-е г.) [Moscow, Russian State Library. Rumyantsev Collection No. 411. Statir, 17th century (80-90)].

\section{Secondary sources}

Antoniy, Radivilovskiy, hegumen. 1696. Огородок Марии Богородицы: Розмаитыми цветами словес на праздники Господския, Богородичны и прочих святых [Marian Lady’s Garden]. Kiev.

Andreev, Alexandr. 2000. Строгановы. Энциклопедическое издание [The Stroganovs. Encyclopaedic Edition]. Moscow.

Bogdanov, Andrey. 2001. Московская публицистика последней четверти XVII в. [Moscow Political Writings of the Last Quarter of the 17th Century]. Moscow.

Chernyh, Alexandr. 2014. Русский народный календарь в Прикамье. Праздники и обряды конца XIX - середины XX в. Ч. IV. Местные праздники [Russian Folk Calendar in Prikamye. Holidays and Rituals of the late 19th - mid 20th Centuries. Part IV: Local Holidays]. St. Petersburg.

Dmitriev, Alexandr. 1892. Пермская старина.Вып. 4 [Permian antiquity. Vol. 4], Perm.

Gromova, Elena. 2005. История русской иконографии Акафиста. Икона «Похвала Богоматери с Акафистом» из Успенского собора Московского Кремля [The History of Russian Iconography of Akafist. Icon «Praise of Our Lady with Akafist» from the Assumption Cathedral of the Moscow Kremlin]. Moscow.

Hegel, Georg Wilhelm Friedrich. 1958. Сочинения. Лекции по эстетике. Т. 14 [Essays. Lectures on Aesthetics. Vol. 14]. Moscow.

Yazykova, Irina.1994. Богословие иконы [The Theology of the Icon]. Moscow.

Kazarinova, Nina; Sysoeva, Tatyana. 2017. Соборный храм Похвалы Богородицы в Орлегородке. История художественного ансамбля [The Cathedral Church of the Praise of the Virgin Mary in Orel-town. History of the artistic ensemble ]. In Художественное наследие Строгановых XVI-XVII веков в музеях Сольвычегодска и Пермского края [The Aartistic Heritage of the Stroganovs of the 16-17 Centuries in the Museums of Solvychegodsk and Perm Territory]. Perm, 596-612.

Kiril, Trankvillion-Stavroveckiy. 1619. Евангелие Учительное [The Teaching Gospel]. Rohmanovo. Lazar', Baranovich. 1666. Меч духовный [Spiritual Sword]. Kiev.

Maleto, Elena. 2003. Образ Богородицы в русском средневековом сознании и его эволюция (по материалам хождений XII-XV вв.) [The Image of the Mother of God in the Russian Medieval Consciousness and its Evolution (based on the materials of the 12th-15th centuries)]. In Исследования по источниковедению истории России (до 1917 г.) [Source Studies in Russian History (pre-1917)]. Moscow, 9-23.

Mezenina, Tatyana; Mosin, Aleksey; Mudrova, Nataliya; Nekliudov Evgeniy. 2007. Род Строгановых. Культурно-исторические очерки [The Stroganov Clan. Cultural and Historical Essays]. Yekaterinburg.

Panchenko, Alexandr. 1984. Русская культура в канун петровских реформ [Russian Culture at the Beginning of Peter's Reforms]. Leningrad. 
Patorzhinsky, M., archpriestt. 1879. Историческая хрестоматия для изучения истории русской церковной проповеди [Historical Textbook for the Study of the History of Russian Church Sermon]. Kiev.

Pivovarova, Nadezhda. 2017. Основные этапы формирования убранства Благовещенского coбopa [Main stages in the formation of the decoration of the Cathedral of the Annunciation]. In Художественное наследие Строгановых XVI-XVII веков в музеях Сольвычегодска и Пермского края [The Aartistic Heritage of the Stroganovs of the 16-17 Centuries in the Museums of Solvychegodsk and Perm]. Perm, 134-155.

Pliuhanova, Marija. 1982. О некоторых чертах личностного сознания в России XVII в. [About Some Features of Personal Consciousness in Russia of the 17th Century]. In Художественный язык Средневековья [The Artistic Language of the Middle Ages]. Moscow, 184-201.

Pliuhanova, Maria. 1995. Сюжеты и символы Московского царства [Plots and Symbols of the Moscow Tsardom]. St. Petersburg.

Polnoe sobranie. 1908. Полное собрание русских летописей. Т. 2. Ипатьевская летопись [The Complete Collection of Russian Chronicles. Vol. 2. The Ipatiev Chronicle]. St. Petersburg. Preobrazhenskiy, Alexandr. 2017. Монументальная живопись Благовещенского собора [Monumental Painting of the Annunciation Cathedral]. In Художественное наследие Строгановых XVI-XVII веков в музеях Сольвычегодска и Пермского края [The Artistic Heritage of the Stroganovs of the 16-17 Centuries in the Museums of Solvychegodsk and Perm]. Perm, 156-257.

Psarev, S. 1909. Акафист Преславной Владычице нашей Богородице и Приснодеве Марии на славянском и русском языках [Akathist to the Most Holy Mother of God and Ever-Virgin Mary in Slavonic and Russian]. In Христианское чтение [Christian Reading] 8-9, 1188-1206. Slova na Pokrov. 1987. Слова на Покров [Homilies on the Holy Shroud]. 1987. In Словарь книжников и книжности Древней Руси : [в 4 вып.]. Отв. ред. Д. С. Лихачёв [и др.]. Вып. 1 : XI - первая половина XIV в. [Dictionary of Scribes and Scribes of Ancient Rus' : [in 4 issues]. Ed. by D. S. Likhachev [et al]. Vol. 1: 11 - first half of 14 century], $421-423$.

Soboleva, Larisa. 2012. Литературные памятники Строгановского региона (XVII - XVIII вв.). «Статир» [Literary Manuscripts of the Stroganov Region (17 - 18 centuries). «Statir»]. In История литературы Урала. Конец XIV - XVIII в. [History of Ural Literature. The End of the 14th to the 18th Century]. Moscow, 158-172.

Soboleva, Larisa. 2020. «Предсказание» из рукописного сборника поучений «Статир»: автор и читатель в переходную эпоху [Author, Time, and Readers in the Prediction from the Handwritten Sermon "Statir"]. In Вестник Екатеринбургской духовной семинарии [Herald of the Ekaterinburg Theological Seminary] 3 (31), 337-368.

Statistika po naimenovaniyam. Статистика по наименованиям православных храмов http:// www.temples.ru/names_stat.php.

Tultceva, Lyudmila. 2001. Престольный праздник в картине мира (мироколице) православного крестьянина [Throne Feast in the Picture of the World (mirokolitsa) of the Orthodox Peasant]. In Православная жизнь русских крестьян XIX-XX вв.: Итоги этнографических исследований [Orthodox Life of Russian Peasants in the 19th -20 th Centuries: Results of Ethnographic Research]. Moscow, 124-167

Turilov, Anatoliy; Kazachkova, Yuliya; Nikiforova Alexandra i dr. 2000. Акафист [Akathist]. In Православная энциклопедия [The Orthodox Encyclopaedia]. T. 1. Moscow, 371-381.

Uspenskiy, Lev. 2001. Богословие иконы [The Theology of the Icon]. Moscow.

Vipper, Yuriy. 1969. О семнадцатом веке как особой эпохе в истории западноевропейских литератур [On the «Seventeenth Century» as a Special Era in the History of Western 
European Literature]. In XVII век в мировом литературном развитии [The 17th Century in the World's Literary Development]. Moscow, 11-60.

Vostokov, Aleksandr Hr. 1842. Описание русских и славянских рукописей Румянцевского Музеума [Description of Russian and Slavic Manuscripts of the Rumyantsevsky Museum]. St. Petersburg, 629-633.

Yahontov, Ivan Petrivich. 1858. Русский проповедник XVII столетия [Russian Preacher of the 17th century]. In Духовная беседа [Spiritual Word]. № 40, 26-38; № 44, 141-149.

Yeremin, Igor. 1948. Ораторская проза второй половины XVII века [Oratory Prose of the Second Half of the 17-th Century]. In История русской литературы: в 10 т. [History of Russian literature: in 10 vol. ]. Moscow, Leningrad. V. 2, 363-367.

Zernova, Anastasiya. 1968. Книги кирилловской печати, изданные в Москве в XVI - XVII веках [Books of the Cyril Press Published in Moscow in the 16-17 centuries]. Moscow.

Zhitie. 1868. Житие преподобного отиа нашего Трибона Вятскаго чудотвориа [Life of Our Vyatka Wonderworker Father Tryphon]. Kazan'.

Znamensky, Petr. 1896. Учебное руководство по истории русской церкви [A Study Guide to the History of the Russian Church]. St. Petersburg.

Dr., Prof. Larisa Soboleva

Ural Federal University named after the first President of Russia B. N. Yeltsin

Ural Humanities Institute

Department of Philology

19, Mira Str.

620002 Yekaterinburg

Russia

l.s.soboleva@mail.ru

ORCID 0000-0002-0694-6687 